\title{
Competition for Resources as a Predictor of Grazing Conflicts in Northern Kenya
}

\author{
Dominic Maringa ${ }^{1, *}$, Mworia Mugambi ${ }^{2}$, Laititi Mutunga ${ }^{3}$ \\ ${ }^{1}$ Ngarendare Forest Trust, Meru, Kenya \\ ${ }^{2}$ Department of Agriculture and Natural Resources, Kenya Methodist University, Meru, Kenya \\ ${ }^{3}$ Department of Education, Kenya Methodist University, Meru, Kenya
}

Email address:

info@ngarendare.org (D. Maringa), mugamworia@kemu.ac.ke (M. Mugambi), laititi@kemu.ac.ke (L. Mutunga)

${ }^{*}$ Corresponding author

\section{To cite this article:}

Dominic Maringa, Mworia Mugambi, Laititi Mutunga. Competition for Resources as a Predictor of Grazing Conflicts in Northern Kenya. International Journal of Natural Resource Ecology and Management. Vol. 5, No. 4, 2020, pp. 168-174. doi: 10.11648/j.ijnrem.20200504.14

Received: October 26, 2020; Accepted: November 13, 2020; Published: November 23, 2020

\begin{abstract}
Competition for grazing resources has been speculated to cause grazing conflicts in Northern Kenya. This study evaluated how pastoral communities compete for seasonal resources leading to grazing conflicts in the region. It was anchored on the theory that competition for limited resources led to livestock movements within and out of conservancies thus triggering conflicts on grazing resources. The study used mixed methods of ecological, remote sensing and social survey design. Purposive sampling was used to select four conservancies out of a population of fifteen, where three of them were communitymanaged while the fourth was privately owned. Lists of grazing committees were obtained, and systematic sampling used to select a population of 106 respondents. Self-administered questionnaires, focused group discussions and content analysis of literature were used to collect social data. The data was analyzed using Statistical Package for Social Sciences (SPSS) version 26. Ecological and bio-physical data on land-use trends were obtained using remote sensing and analyzed using Quantum GIS. The results established that competition accounted for about $45 \%$ of variability of grazing conflicts $\left(\mathrm{R}^{2}=0.449\right)$. It was found that community conservancies had the greatest effects of competition for forage compared to private conservancies. The results were modelled to determine how competition can predict grazing conflicts in the region. The study recommended further investigations on the effects of other factors contributing to grazing conflicts that were not considered, while building capacity to pastoral communities to adhere to grazing plans in order to stem over-grazing and migrations.
\end{abstract}

Keywords: Competition, Grazing Conflicts, Conservancies, Predicting Model

\section{Introduction}

Pastoralism is a form of livelihood that involves keeping livestock mostly occupying the dry arid lands of the Horn of Africa. In recent years, this occupation has been challenged by a number of factors that includes completion for the increasingly dwindling grazing resources that includes water, forage and salt licks [9]. As these shared resources become more scarce over the recent years, and population demands leads to diminished land sizes in the region, interstate conflicts are inevitable in Eastern Africa, as pastoralists traverse the entire region in search of pasture and water. The porous boundaries between the states adds to the misery of the grazing communities, as free movement of large numbers of livestock between them becomes a common sight in the region like was the case between Kenya and Ethiopia during the 2017-18 drought. This makes conflicts management and peace monitoring by government and related agencies in the grazing sector a challenge that has dogged the region for years $[21,30]$.

In times of pasture scarcity especially during drought, Ethiopian grazers often cross the Kenyan border searching for water and pasture. This often leads to competition for the two resources thus sparking a trail of violence and death. Banditry and cattle rustling is also associated with lack of pasture and trans-border clashes between communities of Northern Kenya and Southern Ethiopia [28].

Northern Kenya, being mainly a dry region of scarce grazing resources, is currently undergoing tremendous 
transformation owing to changing geo-political situations as a result of emergence of new governance systems, shrinking resource base due to ever-erratic rainfall patterns, population increase as well as installations of new regional infrastructure [18]. These changes coupled with negative climate trends have compounded challenges facing traditional pastoralism leading to weakened or skewed decision making on handling community grazing in the area. In recent past, conflicts over pasture and other grazing resources have arose as a result of wavering cultural, individual, organizational, governmental and environmental practices which influence resource use and management in the region [17].

The region has become seasonal conflicts hotspot pitting grazers on the one hand against land owners who mostly find themselves at the receiving end especially during drought times. The conflict always negatively affects not only the largescale ranchers, but also the small-scale farmers, traders and wildlife conservationists [21]. As livestock populations increase within a given community grazing areas, the more and more grazing resources are required. This brings in intense competition for forage, water and other browsable resources, constraining the number of livestock that can inhabit a particular conservancy in a given time to match the level of resource supply [22, 23].

As research studies continue to find out the causes and to produce recommendations on mitigating the conflicts, however, the adversities continue undeterred, sometimes leading to fatalities $[15,1,2]$. Most institutions, organizations, and governments use lots of resources in conflict resolution, but without a system of early warning leading to timely actions, conflicts over grazing resources are bound to continue. The communities compete for the scarce resources wherever they occur, thus the resultant scenario is of despair and sometimes leads to confrontation [17].

\subsection{Objectives}

The overall objective of this study was to find out how competition for grazing resources in a particular area can be synthesized to develop a conflicts predicting model. The Specific objective was to:

1) To establish the communities perception of competition for grazing resources

2) To establish how competition for grazing resources leads to grazing conflicts

3) To develop a conflicts predicting model based on competition for resources in Northern Kenya

\subsection{Hypothesis}

The study used research hypothesis specifically for objective (3), where competition for resources was taken as independent variable and influencer of grazing conflicts (dependent variable), which therefore helped the study to test the following hypothesis:

$\mathrm{H}_{1}$ : Competition for resources has a significant influence on grazing conflicts in northern Kenya.

$\mathrm{H}_{0}$ : Competition for resources has no significant influence on grazing conflicts in northern Kenya.

\section{Methods}

This research adopted a mixed-method that combined qualitative and quantitative approaches. It used philosophical assumptions, ecological, and remote sensing approaches to collect, organize and analyse the data $[11,21]$. The mixed methods design was chosen since it involves triangulation of several designs to increase strength and validity of the outcomes, as well as to compensate for the weaknesses of any one of them when used singly [19]. Specifically, this approach included ecological methods which involved field plots, quadrants and transect walks [4, 3]; Social economic approaches included administration of questionnaires, interview schedules, Focus Group Discussions (FGDs) and desk research, while remote sensing methods included the use of GIS to analyse temporal and spatial vegetation trends.

\subsection{The Study Area}

This study was undertaken in four conservancies distributed within two counties of Northern Kenya, namely Laikipia and Isiolo. These are Ngarendare, Ingwesi, Nasuulu and Lewa. The two counties have almost similar geophysical and climatic characteristics and are adjacent to each other, with Laikipia bordering Isiolo to the Northwest. The two counties have experienced the worst of grazing conflicts in recent years. They are both of national geo-political and economic importance, with Laikipia being the second largest tourism catchment area in Kenya after the Mara and Isiolo set to be a result city according to Kenya Vision 2030. Both counties host the largest number of livestock in Kenya with grazing resources communally managed, besides being the only region in Kenya where community conservancies and large-scale ranching are found adjacent to each other.

\subsection{Ecological Methods}

Two sites were located within each of the conservancies grazing field, and a plot of $50 \mathrm{~m} \times 50 \mathrm{~m}$ set on each site. The sites were selected based on representation of variations characteristics of entire grazing field like slope direction, forage species, vegetation growth forms and accessibility [29, 22]. Each plot contained 50 sub-plots (quadrants) measuring $1 \mathrm{mx} 1 \mathrm{~m}$ each. To estimate available forage biomass, five quadrants were picked at random and 'clip-dry-weigh' method used to estimate the biomass levels of standing herbage (grass) in both wet and dry seasons [14]. A clipping frame of $0.5 \mathrm{~m} \times 0.5 \mathrm{~m}$ was placed on the subplot and all above ground grass cut using secateurs $[29,8]$. The forage was weighed and oven dried and tables of quantities and graphs were used to present the data.

\subsection{Social Survey}

The survey focused on the resource persons, grazing committees, key informants and experts within each community conservancy. Respondents were committee 
members systematically picked from lists of each conservancy and the questionnaires administered. Four (4) focused group discussions composed community leaders of between 8-12 people were conducted [13]. Key informants and experts were interviewed to clarify controversial issues in the course of research. The survey data was analyzed using SPSS version 26. Results were presented in graphs, tables, and accumulation curves.

\subsection{Remote sensing techniques}

Remote sensing techniques included production of Normalized Difference Vegetation Indices (NDVI) of the spatial and temporal vegetation changes within the study area for the year 2018 [21]. Participatory GIS (PGIS) was used to obtain data from lay knowledge of the indigenous people to correlate with ecological and social data. The satellites imagery were produced using Quantum Geographical Information System (QGIS), which showed trends in forage levels and land-use changes[26].

\section{Results}

\subsection{Competition for Forage and Stocking Rates}

The study established the communities' perception about competition for limited grazing resources in their conservancies among different types of stock. Table 1 shows the responses on stock competition, livestock numbers and overstocking:

Table 1. Stock numbers and competition per conservancy.

\begin{tabular}{|c|c|c|c|c|c|c|}
\hline \multirow{2}{*}{$\begin{array}{l}\text { Estimation of the Number of Cattle } \\
\text { Statistics }\end{array}$} & \multicolumn{2}{|c|}{ 0-1000 } & \multicolumn{2}{|c|}{$1000-5000$} & \multicolumn{2}{|c|}{5000 And Above } \\
\hline & $\mathrm{Fq}$ & $\%$ & $\mathrm{Fq}$ & $\%$ & $\mathrm{Fq}$ & $\%$ \\
\hline Ngarendare & 27 & 100 & 0 & 0 & 0 & 0 \\
\hline Ilngwesi & 20 & 80 & 5 & 20 & 0 & 0 \\
\hline Nasuulu & 17 & 80 & 4 & 20 & 0 & 0 \\
\hline Lewa & 12 & 100 & 0 & 0 & 0 & 0 \\
\hline Total & 76 & 89 & 9 & 11 & 0 & 0 \\
\hline Whether Conservancies Mixed the Goat and Sheep & \multicolumn{2}{|l|}{ Yes } & \multicolumn{2}{|c|}{ No } & \multicolumn{2}{|c|}{ Sometimes } \\
\hline Statistics & $\mathrm{Fq}$ & $\%$ & $\mathrm{Fq}$ & $\%$ & $\mathrm{Fq}$ & $\%$ \\
\hline Ngarendare & 18 & 70 & 4 & 15 & 5 & 16 \\
\hline Ilngwesi & 25 & 100 & 0 & 0 & 0 & 0 \\
\hline Nasuulu & 21 & 100 & 0 & 0 & 0 & 0 \\
\hline Lewa & 0 & 0 & 12 & 100 & 0 & 0 \\
\hline Total & 64 & 75 & 16 & 18 & 5 & 6 \\
\hline Whether there was Overstocking & \multicolumn{2}{|l|}{ Yes } & \multicolumn{2}{|l|}{ No } & \multicolumn{2}{|c|}{ Sometimes } \\
\hline Statistics & $\mathrm{Fq}$ & $\%$ & $\mathrm{Fq}$ & $\%$ & $\mathrm{Fq}$ & $\%$ \\
\hline Ngarendare & 3 & 10 & 15 & 55 & 8 & 33 \\
\hline Ilngwesi & 10 & 40 & 10 & 40 & 5 & 20 \\
\hline Nasuulu & 10 & 48 & 5 & 20 & 6 & 29 \\
\hline Lewa & 0 & 0 & 12 & 100 & 0 & 0 \\
\hline Total & 23 & 27 & 42 & 49 & 19 & 22 \\
\hline
\end{tabular}

As seen on Table 1, it was found that most members of conservancies acknowledged about existence of competition between goats, sheep and cows as indicated by $68.4 \%$ of respondents

\subsubsection{Perception on Effects of Livestock Numbers on Grazing Conflicts}

From the results, Ngarendare conservancy contained the biggest number of livestock, followed by Ilngwesi, and Nasuulu then finally Lewa had the least number of livestock. The results were compared across the conservancies to find out whether there were significant differences, and the findings were as shown in table 2;

Table 2. Livestock numbers per conservancy: Chi-Square Tests.

\begin{tabular}{llll}
\hline & Value & Df & Asymp. Sig. (2-sided) \\
\hline Pearson Chi-Square & $43.388^{\text {a }}$ & 3 & .000 \\
Likelihood Ratio & 54.324 & 3 & .000 \\
Linear-by-Linear Association & 41.838 & 1 & .000 \\
N of Valid Cases & 97 & & \\
\hline
\end{tabular}

a. 0 cells $(0.0 \%)$ have expected count less than 5 . The minimum expected count is 5.81 . 
The results show that there were statistically significant differences on stocking rates and competition for grazing resources per conservancy as shown by chi-square $<0.05$.

\subsubsection{Methods of Grazing Practiced by the Communities and Grazing Conflicts}

The study also enquired about the methods of grazing prevalent on the conservancies and the communities' perception on their effects on the grazing conflicts. This was aimed at finding out whether the communities mixed shoats and the larger stock (cattle) in order to make conclusions on the competition between species. The results from cross tabulation of the frequency of responses for this question are as shown in Figure 1:

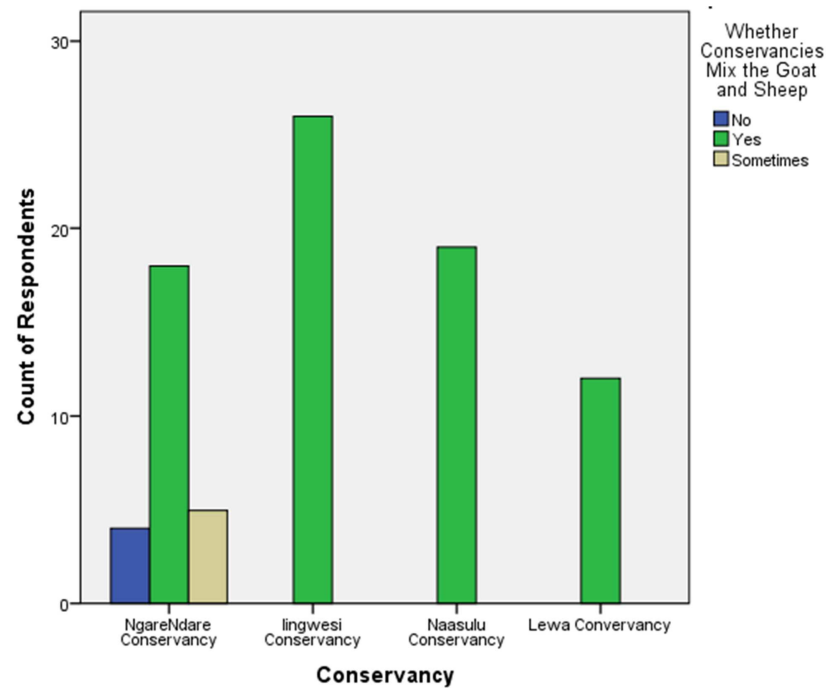

Figure 1. Mixing of livestock per conservancy.

From the results of the frequency counts, the study found out that all conservancies mixed goat and sheep and that there was no significant differences on their effects on grazing conflicts as shown in Table 3:

Table 3. Mixing of stock per conservancy: Chi-Square Test.

\begin{tabular}{llll}
\hline & Value & df & Asymp. Sig. (2-sided) \\
\hline Pearson Chi-Square & $21.280^{\mathrm{a}}$ & 6 & .092 \\
Likelihood Ratio & 22.832 & 6 & .001 \\
Linear-by-Linear Association & .144 & 1 & .704 \\
N of Valid Cases & 84 & & \\
\hline
\end{tabular}

a. 8 cells $(66.7 \%)$ have expected count less than 5 . The minimum expected count is. 57 .

\subsection{Remote Sensing Analysis of Competition and Grazing Conflicts}

The relationship between competition for grazing resources and occurrence of grazing conflicts were studied using remote sensing where annual forage availability was analysed using QGIS (7), to produce annual Normalised Difference Vegetation Indexis (NDVI) for 2018, which was overlaid with occurrence of grazing conflicts and the results were as follows:

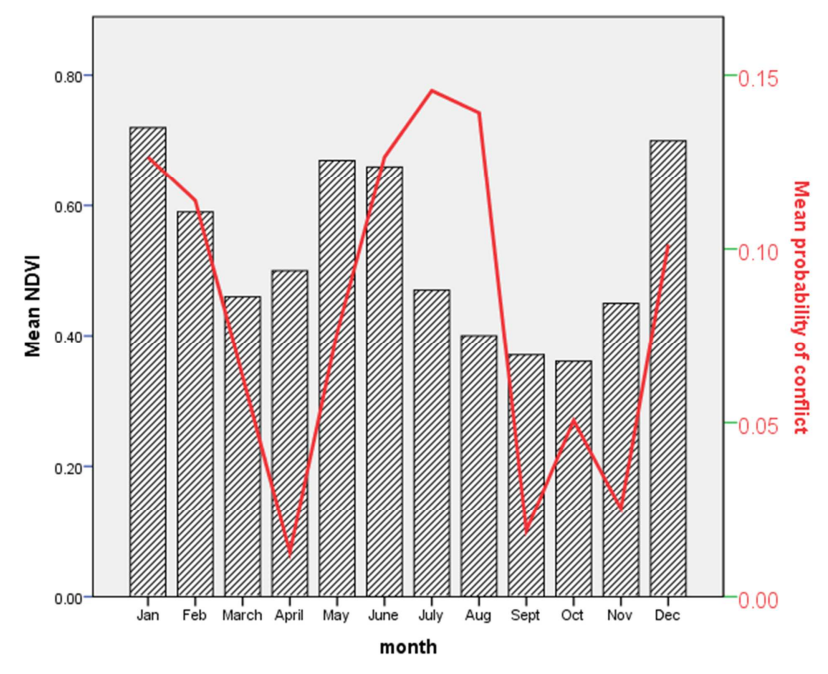

Figure 2. Correlation between forage availability and grazing conflicts.

From Figure 2, it can be deduced that forage availability as a grazing resource is a good predictor of grazing conflicts whereby during the wet season, pastoralists want to restock their lost livestock, thus sparking cattle rustling and related conflicts in the area. From the interviews, respondents asserted that there is usually competition among members to restock after most of their livestock were devastated by severe drought, and in anticipation of good forage the following season, there is increase in cattle thefts, migrations and related conflicts, which were consistent with the findings of Pkalya, Muhamud \& Masinde, [24].

As figure 2 shows, it can be deduced that most conflicts occurred in the period between May and July, and a recurrence was witnessed between December and February. These are the periods of general forage boom in the region immediately after the rains as depicted by seasonal NDVI.

Periods between July and November are the most peaceful months of the year, while they were also the periods with the lowest amount of rainfall. The findings concurs with previous research [16], whereby respondents asserted that during droughts there were less conflicts as a result of cattle rustling since there was nowhere to take stolen stock.

\subsection{Modelling Effects of Competition for Resources on Grazing Conflicts}

Competition for grazing resources was taken as independent univariate variable and was regressed against the grazing conflicts to find out whether the model accounted for any variations in the dependent variable, the grazing conflicts (Mugenda \&Mugenda, 2004). The results were as shown in Table 4:

Table 4. Competition for resources: Model Summary.

\begin{tabular}{lllll}
\hline Model & R & R Square & Adjusted R Square & Std. Error \\
\hline 1 & $.522^{\text {a }}$ & .449 & .042 & 3.91337 \\
\hline
\end{tabular}

a. Predictors: (Constant), Competition 
The findings in Table 4 shows the value of $\mathrm{R}^{2}$ as 0.449 , which meant that $45 \%$ of the total variance in grazing conflicts could be accounted for by competition for resources.

A one way Analysis of Variance (Anova) on competition factor provided information about levels or directions of variability within the regression model which formed the basis for hypothesis testing. Table 5 shows the Anova results of competition analysis against the dependent variable:

Table 5. Competition for resources: Anova.

\begin{tabular}{llllll}
\hline ANOVA $^{\mathbf{a}}$ & & & & & \\
\hline Model & & Sum of Squares & Df & Mean Square & F \\
\hline \multirow{3}{*}{1} & Regression & 101.475 & 1 & 101.475 & 16.626 \\
& Residual & 1960.248 & 128 & 15.314 & \\
& Total & 2061.723 & 129 & & \\
\hline
\end{tabular}

a. Dependent Variable: Grazing conflicts

b. Predictors: (Constant), Competition

Table 5 is a one-way Anova, showing that the effects of competition on grazing conflicts was partially significant, $\mathrm{F}(1,130)=16.626$, p.041>.050). Therefore the null hypothesis was rejected and study concluded that there was positive relationship between grazing conflicts and competition for grazing resources. This meant that competition for resources (independent) was a good predictor of grazing conflicts (dependent).

In order to find the kind of relationship between the two variables, Beta coefficient was examined to show the degree of change in the outcome dependent variable for every unit change in the competition for resources [10]. The findings were as shown in Table 6:

Table 6. Competition for resources: Beta Coefficient.

\begin{tabular}{|c|c|c|c|c|c|c|}
\hline \multicolumn{7}{|c|}{ Coefficients $^{\mathrm{a}}$} \\
\hline \multirow{2}{*}{ Model } & & \multicolumn{2}{|c|}{ Unstandardized Coefficients } & \multirow{2}{*}{$\begin{array}{l}\text { Standardized Coefficients } \\
\text { Beta }\end{array}$} & \multirow{2}{*}{ t } & \multirow{2}{*}{ Sig } \\
\hline & & B & Std. Error & & & \\
\hline \multirow{2}{*}{2} & (Constant) & 10.180 & 1.936 & & 5.259 & .00 \\
\hline & Competition & .066 & .204 & .012 & .323 & .77 \\
\hline
\end{tabular}

The t-test established that there was a significant difference between the predictor (competition) and the outcome variable. That holding all other factors constant, a unit increase or decrease in competition for resources would lead to an increase or decrease in grazing conflicts by $1.2 \%$. This shows that competition for resources exhibited positive effects on the independent variable, and therefore a good predictor of grazing conflicts in the study area.

\section{Discussion}

From the findings in Table 1, most respondents (89\%) indicated their conservancy sometimes held above 1000 cattle and sheep while only $11 \%$ estimated the number to be below 1000. This was supported by the focus group discussion where most members indicated observing large numbers of livestock from time to time in their conservancies. According to them, the movements of large populations of livestock from other areas increased competition for resources leading to various forms of conflicts within the conservancies, and the results were agreeing with the findings of Bonneau, [5]. The figure below is a testimony of how competition for forage on community conservancies compare to the plenty on private conservancies:

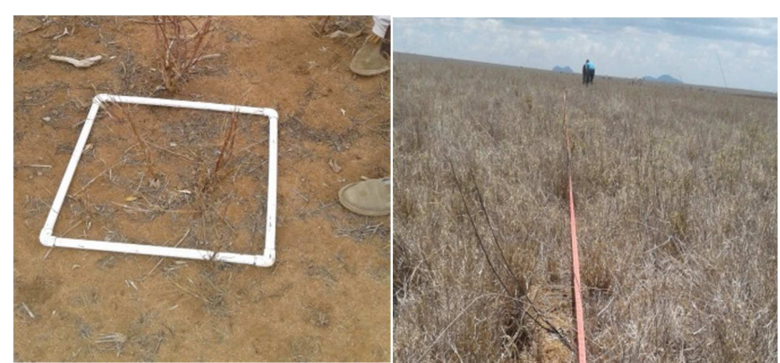

Figure 3. Heavily browsed forbs on Ilngwesi versus forage field on Lewa.(Pic by Dominic Maringa. 17-04-2017).

The results also concurred with the findings of Rutagwenda and Wanyoike [25] who found that mixing browsing species have significant effects on the availability of forage. From the results, $84 \%$ of the respondents indicated that overstocking led to overgrazing in their conservancy while $16 \%$ indicated that it did not, which also tends to support the findings of Brannstrom \& Sumpter [6]. The grazing committees acknowledged occurrence of competition for browse between shoats and cattle since the shoats browse faster on the newly germinated herbs unlike cattle. Therefore, cattle migrated away immediately after the short rains in search of pasture. These results support the findings by Taylor [27] in his study of the study in Northern Kenya.

While explaining that during droughts all neighborhoods experience pasture scarcity and it is only inside the private 
conservancies that pasture remains compared to community grazing areas like group ranches, conflicts arise since everyone competes for the limited resource. This was partly due to the fact that grazing in the private conservancy was well managed and it was therefore the only fallback resource. Similar findings have been obtained by Rutagwenda \& Wanyoike [25, 27, 22]. From the figure 1, it can be seen that conservancies mixed all types of livestock in the same grazing set up. This means there was competition for forage between goats, sheep and cattle. This study did not interrogate the levels of competition between different types of livestock and their effects on available forage, though it was brought up in the focused group discussions that there exists competition for grass between different species.

\section{Conclusions and Recommendations}

The present study showed that during the dry season, most community conservancies were faced with dwidling forage availability leaving most of livestock to migrate to further areas where they could find grass. It also meant that the productivity of the conservancy varied in the dry season with other factors, which was consistent with the findings of Fahey, Collins, Mertens \& Moser, [12]. From the findings, the limited resources scenario meant that more stock scrambled for dwindling pasture and water resources therefore causing competition which lead to grazing conflicts and other environmental externalities. The big stock was migrating away immediately after the short rains, leaving sheep and goats to browse longer on the ground liter and perennial shrubs. The private conservancies showed greatest availability of forage and less competition owing to prudent resource management compared to community conservancies [21]. This study therefore contributes to theory in espousing which and how grazing resources, environmental and human factors contribute to grazing conflicts in Kenya. The study came up with new knowledge on using social and ecological factors to build models that can predict grazing conflict. The study recommends further research on competition for pasture and water resources between different species of livestock and wildlife in order to advise the grazers, stakeholders and policy developers on stocking under limited resources.

\section{References}

[1] Abdile, A., (2017). Ethnic Contest and Electoral Violence in Northern Kenya. International Crisis Group. https://www.crisisgroup.org/africa/horn-africa/kenya/ethniccontest-and-electoral-violence-Northern-kenya

[2] Adan, M. \& R. Pkalya (2006). The Concept Peace Committee. A Snapshot Analysis of the Concept Peace Committee in Relation to Peacebuilding Initiatives in Kenya. PracticalAction. Retrieved from: http://unpan1.un.org/intradoc/groups/public/documents/UN/U NPAN032127.pdf
[3] Beesom, S. L., \& Haucke, H., (1975). A comparison of four distance sampling techniques in South Texas live oak mottes. Journal of Range Management 28:142-144.

[4] Bonham, C. D., (1989). Measurements for terrestrial vegetation. John Wiley Sons, New York. Pp. 159-164.

[5] Bonneau, P., (2013). Drought and Internal Displacements of Pastoralists in Northern Kenya in 2012: An Assessment. Retrieved from: http://labos.ulg.ac.be/hugo/wpcontent/uploads/sites/38/2017/11/The-State-of-EnvironmentalMigration-2013-101-116.pdf

[6] Brännström, A. \& Sumpter, D. J. T., (2005). "The role of competition and clustering in population dynamics" (PDF). Proceedings of the Royal Society of London B: Biological Sciences, 275:2065-2072.

[7] Clarke, K. C. (1986). Recent trends in Geographic Information System research GeoProcessing, vol. 3, no. 1, pp. $1-16$.

[8] Cottam, G., \& Curtis. J. T., (1956). The use of distance measure in phytosociological sampling. Ecology 37:451-460.

[9] Cornelia, H., \& Elisabeth H., (2014). Pastoralism and conflict - two sides of a coin? Journal of Rural21. November 2014 ISBN / Resource ID: Rural21-Vol: 48-Nr:4/2014Article:5https://www.togev.de/fileadmin/gfx/Presse/Artikel P ublikationen/rural21Pastoral_conflict_c.heine-2014.pdf

[10] Cortina, B., (1993). "Coefficients Alpha, Beta, Omega, and the glb: Comments on Sijtsma". Psychometrika. 74 (1): 145-154. doi:10.1007/s11336-008-9102-z.

[11] Creswell, J. W., \& Plano-Clark, (2007). Designing and Conducting Mixed Method Research. Vol. $22^{\text {nd }}$ Ed.

[12] Fahey, G. C, Jr. Collins. M., Mertens, D. R., \& Moser. L. E., (1994). Forage Quality, Evaluation, and Utilization. Based on the National Conference on Forage Quality, Evaluation, and Utilization held at the University of Nebraska, Lincoln, on 1315 April 1994. Retrieved from: https://dl.sciencesocieties.org/publications/books/pdfs/acsessp ublicati/foragequalityev/frontmatter?noSSO $=1 \& \mathrm{t}=6$

[13] Foley, B., (2018).Purposive Sampling 101. Retrieved from: https://www.surveygizmo.com/resources/blog/purposivesampling-101/Sampling 10

[14] Henderson, P. A., (2012). Ecological Methods. Pisces Conservation Ltd, Hampshire, England DOI:10.1002/9780470015902.a0003271.pub2.Retrievedfrom http://www.els.net/WileyCDA/ElsArticle/refId-a0003271.html

[15] Houreld, K., (2017). Drought stokes battle for pastures in Kenya's Northern regions. Thomson Reuters. https://reliefweb.int/report/kenya/drought-stokes-battlepastures-kenyas-Northern-regions Accessed 13-08-2018.

[16] IRIN, (December, 18 $\left.18^{\text {th }}, 2009\right)$. KENYA: 'What drives conflicts in Northern Kenya', The Inside Story. (IRIN News). https://www.globalsecurity.org/military/library/news/2009/12/ mil-091218-irin01.htm

[17] Juma, F., (2015). Pastoralists Map Grazing Lands for Survival and Security in Northern Kenya. Relieveweb. News and Ptress Release: Posted $4^{\text {th }} \quad$ Jan, 2015: https://reliefweb.int/report/kenya/pastoralists-map-grazinglands-survival-and-security-northern-kenya 
[18] Kaye-Zwiebel, E., \& E. King. (2014). Kenyan pastoralist societies in transition: Varying perceptions of the value of ecosystem services. Ecology and Society: 19 (3). 17.

[19] Kihara, M. P., (2017). Influence of strategy implementation on the performance of manufacturing small and medium firms in Kenya. Retrieved from: https://scholar.google.com/citations

[20] MacArthur, R. H., (1972). Geographical Ecology: Patterns in the Distribution of Species.

[21] Maringa, D., Mworia M., Gichuki, N., (2018). Application of Remote Sensing Techniques To Assess Temporal and Spatial Availability of Forage in Relation to Grazing Conflicts In Northern Kenya. International Journal of Advanced Research and Publications. Vol 2 (1), Jan 2018. Pg27-33. http://www.ijarp.org/published-researchpapers/jan2018/Application-Of-Remote-Sensing-TechniquesTo-Assess-Temporal-And-Spatial-Availability-Of-Forage-InRelation-To-Grazing-Conflicts-In-Northern-Kenya.pdf

[22] O'Connor, D. A., Bilal. B., \& Joahannes B. F., (2015). Foraging ecologies of giraffe (Giraffa camelopardalis reticulata) and camels (Camelus dromedarius) in Northern Kenya: effects of habitat structure and possibilities for competition? Retrieved from: https://onlinelibrary.wiley.com/doi/full/10.1111/aje.12204

[23] Opiyo, E. O., Wasonga. V. O., Schilling J., \& Mureithi. M., (2012). Resource-based conflicts in drought-prone Northwestern Kenya: The drivers and mitigation. Wudpecker Journal of Agricultural Research Vol. 1(11), pp. 442 - 453, December 2012 Available online at http://www.wudpeckerresearchjournals.org

[24] Pkalya, R, Adan. M, Masinde. I., (2003). Conflict in Northern
Kenya: A focus on the internally displaced conflict victims in Northern Kenya. Retrieved from:

https://practicalaction.org/conflict-in-Northern-kenya

[25] Rutagwenda., T., \& Wanyoike. M., (1994). Seasonal changes in livestock diets in a semi-arid environment in Northern Kenya. Department of Animal Production, Faculty of Veterinary Medicine, University of Nairobi, Kenya. Retrieved from: http://www.fao.org/wairdocs/ilri/x5519b/x5519b09.htm

[26] Smith, W. B., P. D. Miles, J. S. Vissage, \& S. A. Pugh (2004). Forest resources of the United States, 2002. USDA Forest Service. http://ncrs.fs.fed.us/pubs/gtr/gtr_nc241.pdf

[27] Taylor, R. L., (2015). Battle of the Kenyan Herbivores: Resource Competition between Native and Domesticated Animals. Retrieved from: https://nature.berkeley.edu/classes/es196/projects/2015final/Ta ylorR_2015.pdf

[28] Thomson Reuters Foundation, (2006). Kenya: Clashes over water, pasture kill 40 in east Africa. Accessed 27-09-2018. https://reliefweb.int/report/kenya/kenya-clashes-over-waterpasture-kill-40-east-africa

[29] University of Idaho, (2009). Direct Measures of Biomass. In: Principles of Vegetation Measurement \& Assessment and Ecological Monitoring \& Analysis. Accessed 02-01-2019 https://www.webpages.uidaho.edu/veg measure/Modules/Les sons/Module\%207(Biomass\&Utilization)/7_3_Direct\%20Met hods.htm

[30] Wafula, O., (2010). Resources and border disputes in Eastern Africa. Journal of Eastern Africa Studies. Vol 4 (2). Pg 279 297 |. https://doi.org/10.1080/17531055.2010.487338 